African Crop Science Journal by African Crop Science Society is licensed under a Creative Commons Attribution 3.0 Uganda License. Based on a work at www.ajol.info/ and www.bioline.org.br/cs DOI: http://dx.doi.org/10.4314/acsj.v25i1.2S

\title{
ADOPTION OF SOIL CONSERVATION THROUGH COLLECTIVE ACTIONS IN SOUTHWESTERN UGANDA
}

\author{
R.M. KALIBWANI, M. KAKURU, R. KAMUGISHA ${ }^{1}$, J. TWEBAZE ${ }^{2}$, E. HILMAN², \\ H. TUMUHEIRWE ${ }^{2}$, M.M. TENYWA ${ }^{3}$, S.O. NYAMWARO ${ }^{4}$, J. MUGABO ${ }^{5}$, R. BURUCHARA 6 , \\ A.O. FATUNBI ${ }^{7}$ and A. ADEKUNLE ${ }^{7}$ \\ Bishop Stuart University, Department of Agriculture and Agribusiness, Mbarara, Uganda \\ ${ }^{1}$ World Agro-forestry Centre (ICRAF), Kawanda, Uganda \\ ${ }^{2}$ Kabale District Local Government, Kabale, Uganda \\ ${ }^{3}$ College of Agricultural and Environmental Sciences, Makerere University, P. O. Box 7062, Kampala, Uganda \\ ${ }^{4}$ International Centre for Tropical Agriculture (CIAT-U), Kawanda-Uganda \\ ${ }^{5}$ Rwanda Agricultural Board (RAB), Kigali-Rwanda \\ ${ }^{6}$ International Centre for Tropical Agriculture (CIAT-Africa), Nairobi-Kenya \\ ${ }^{7}$ Forum for Agricultural Research in Africa (FARA), Accra-Ghana \\ Corresponding author: rmkalibwani@yahoo.com,rmkalibwani@as.bsu.ac.ug
}

\begin{abstract}
In developing countries, access to and use of renewable natural resources are essential for rural livelihoods to thrive. Hence, cooperation in the management of natural resources is increasingly an important strategy that can enhance long-term socio-ecological resilience. In most cases, collective actions have widely been recognised as an alternative institutional arrangement to centralised governance for the management of natural resources, but their success largely depends on factors that are specific to localities where they are implemented. In this study, factors that influence adoption and extent of adoption of natural resource conservation activities were identified using two case studies: Bubaare and Bufundi Innovation Platforms in Uganda. The drivers of adoption of community natural resource management strategies are analysed using an Ordered Logit Model while extent of adoption is analysed using a truncated regression model. The education level of a household head, membership in collective action group, and perception of plot slope and relevance of bye-laws were factors associated with likelihood of adoption. Value of livestock, membership in collective action group, access to credit and off-farm income were found to positively influence the level of investment. Thus, collective action increases opportunities for adoption; hence farmers should be supported to work collectively.
\end{abstract}

Key Words: Adoption, collective action, natural resource management, soil conservation

\section{RÉSUMÉ}

Dans les pays en voie de développement, l'accès et l'utilisation des ressources naturelles sont essentiels pour la suivie en mileu rural et pour y prospérer. Ainsi, la coopération dans la gestion des ressources naturelles est de plus en plus une stratégie importante qui peut améliorer à long terme la cohésion socio-écologique. Dans beaucoup de cas; les actions collectives ont été largement reconnues comme une alternative d'organisation institutionnelle pour centraliser la gouvernance de la gestion des ressources naturelles, mais leur succès dépend largement des facteurs qui sont spécifiques aux milieux où elles sont mise en oeuvre. Dans cette étude, les facteus qui influencent l'adoption et le degré d'adoption des activités de conservation des ressources naturelles étaient identifiés en utilisant deux cas d'étude: Les Plate-formes d'Innovation de Bubaare et Bufundi en Ouganda. Les forces motrices d'adoption des strategies de gestion des ressources naturelles communautaires sont analysées en utilsant un modèle Logit Ordonné tandis que le degré d'adoption est analysé en utilisant un modèle de régression tronqué. Le 
niveau d'éducation du chef de ménage, l'appartenance au groupe d'action collective, et la perception de la pente de la parcelle et limportance des arrêtés étaient les facteurs associés au taux d'adoption. La value du bétail, l'appartenance au groupe d'action collective, l'accès au crédit et le revenu non- agricole étaient les facteurs qui influencent positivement le niveau d'investissement. Donc, les actions collectives augmentent les opportunités pour l'adoption; ainsi les producteurs devraient être encouragés à travailler de façcon collective.

Mots Clés: Adoption, action collective, conservation du sol, gestion des ressources naturelles

\section{INTRODUCTION}

In developing countries where access to and use of renewable natural resources were essential to rural livelihoods, improving cooperation in their management is increasingly an important element in strategies that can enhance long-term socio-ecological resilience (Ratner et al., 2013). Traditionally, the importance of renewable natural resources in reducing poverty and building peoples' assets is well recognised, and there is emerging awareness of the positive potential that cooperation of the resource users in collective action can offer in addressing the natural resource challenges (Ratner et al., 2013).

Collective action is where individuals undertake collective effort based on mutual interests and the expectation of mutual benefits (ICRA, 2012). Collective action is also defined as action by more than one person directed towards the achievement of a common goal or the satisfaction of a common interest that cannot be obtained by an individual acting on his own (Wade,1987). The International Centre for development oriented Research in Agriculture (ICRA) learning resources identify several types of collective action, depending on the type of work and action. The types of work might include group work, whereby all members are required to do the work together such as cleaning a common irrigation canal; organised work whereby all members are required to do the work, but not together; and independent work, whereby all members are required to do the work, but they can work independently (ICRA, 2012).

The types of action include physical, where members do physical work, contribute by cash or in kind instead of physically, and regulation whereby members prohibit something, supervise or enforce regulations. The overriding principle is that collective action needs to be tailored differently to suit the individual scenarios, when it is required (ICRA, 2012).

The intensively cultivated and densely populated southwestern highlands of Uganda are characterised by fragile agroecology, with a combination of uses, and users (Sanginga $e t$ $a l ., 2007)$, and already experiencing land degradation most especially from water erosion. Given that the Government of Uganda has enacted a decentralisation policy that allows local governments to design regulations for their specific local needs, the highlands of southwestern Uganda could benefit from NRM to combat this situation. Specifically, in this location, the type of collective action that is considered appropriate is where the people work together, either in a group or independently, to construct soil and water conservation structures in their respective gardens, in order to protect entire landscapes from degradation.

The objective of this study was to evaluate the effect of collective actions and identify factors that influence adoption and extent of adoption of soil conservation technologies in Southwestern Uganda.

\section{METHODOLOGY}

Study area and data collection. The study was conducted in Kabale district, which is part of the Lake Kivu Pilot Learning Site (LKPLS) of the Sub-Saharan Challenge Program (SSA $\mathrm{CP})$. Kabale district is located in the 
southwestern highlands of Uganda, and is one of the highest densely populated rural districts in Uganda. The steep slopes of the highlands, coupled with the dense population, have over time resulted into soil erosion and land degradation due to massive cultivation of the fragile lands. These conditions necessitate that NRM becomes a central theme of any rural development agenda.

Subsequently, there has been intervention through the Trans-boundary Agro-ecosystem Project for the Kagera River Basin (KageraTAMP) project of the Food and Agriculture Organisation (FAO), and the Anglican Church of Uganda, through the Diocese of Kigezi. Although the two initiatives address different issues in their respective area of operation, NRM is part and parcel of their programme and both initiatives operationalise the subcounty NRM bye-laws.

Two sub-counties (Bubare and Bufundi) were selected. These were sub-counties where the Sub-Saharan Africa Challenge Program (SSA-CP) in 2008, established Innovation Platforms (IPs), one in each sub-county, for the development of an identified commodity value chain; sorghum in Bubare and potato in Bufundi. Given the terrain in Kabale district, the adoption of soil conservation that would be critical for the production of the two commodities, would greatly benefit from collective community efforts. The two IPs were facilitated to implement the community NRM bye-law.

Data were obtained from respondents using a case study approach. Two case studies were done; one from Kagarama farmer field school, and the other from the gravity flow scheme initiative of Kacerere Church of Uganda. A total of 117 respondents (61 from Kagarama

and 56 from Kacerere) were randomly selected from a list of registered members of each group, with the help of the respective chairpersons.

A structured questionnaire was used to collect data from the respondents through face to face interviews. Focus group discussions with key informants were held in each of the two parishes. There were 9 members in Kacerere (Bufundi), and 22 in Kagarama (Bubare), comprising of respective group and local community leaders.

Theoretical modelling. Participation in collective action was measured by the adoption of the NRM bye-laws. Three levels of adoption (no adoption, partial adoption and full adoption) were distinguished depending on the number of NRM activities done by a respondent. The no-adoption category consisted of households that adopted none of the selected activities of the NRM bye-law, the partial adoption category consisted of those that adopted at least one of the activities, while the full adoption category consisted of those that adopted all the selected activities.

This type of data set was modelled via a latent (unobserved) variable model given by (Greene, 2002):

$Y_{i}^{*}=\alpha+\beta_{i} X_{i}+\varepsilon$ Equation 1

Where: $Y_{i}^{*}=$ Latent unobserved measure of the level of adoption by the respondent; $X_{i}=\mathrm{A}$ vector of explanatory variables; $a, b_{i}$ are coefficients to be estimated; and $\varepsilon$ is a random error term (assumed to follow a standard normal distribution for logistic distribution). The observed or defined categorical adoption variable $Y_{i}$ is determined from the model as follows (Greene, 1997):

$$
Y_{i}=\left\{\begin{array}{c}
0 \rightarrow \text { No adoption if } Y_{i}^{*} \leq 0 \\
1 \rightarrow \text { Partial adoption if } 0<Y_{i}^{*} \leq \mu_{i} \\
2 \rightarrow \text { Full adoption if } Y_{i}^{*}>\mu_{i}
\end{array}\right.
$$

Where: $\mu_{i}$ is a set of thresholds of the adoption gap to be estimated with the parameter vector $\beta$ and $\alpha$. The probability associated with the coded responses of an ordered probability model is as follows: 
$\operatorname{Pr}\left(Y_{i}=j\right)=\operatorname{Pr}\left(\mu_{j-1}<Y_{i}^{*} \leq \mu_{j}\right)=\operatorname{Pr}\left(\mu_{j-1}<\left[\alpha+\beta_{i}\right.\right.$ $\left.\left.X_{i}+\varepsilon\right] \leq \mu_{j}\right) \ldots \ldots \ldots \ldots \ldots \ldots \ldots \ldots \ldots \ldots . .$. Equation 3

Where: $j$ represents the ranked value of adoption. The random error term "" is such that:

$\operatorname{Pr}\left(Y_{i}=j\right)=\operatorname{Pr}\left(\mu_{i-1}<Y_{i}^{*} \leq \mu_{j}\right)=F\left(\mu_{i}-\alpha-\beta_{i} X_{i}\right)-$

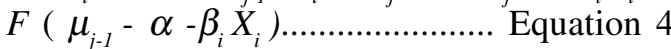

Where: $F($.$) is the logistic cumulative$ distribution function for $\varepsilon$.

To estimate the probabilities from survey data, an ordered logistic distribution was used since it offers the most convenient closed form cumulative distribution function (Train, 2003).

Empirical model. Following the theoretical specification in Equation 1, the empirical model used to specify adoption level $j$ by respondent $i$ is a function of the factors that influence adoption (Feleke and Zegeye, 2006). The systematic part of the specification (1) of respondent $i$ associated with level of adoption $j$ is modeled as a linear function:

$Y_{i j}=\alpha+\beta_{1} X_{1 i}+\beta_{2} X_{2 i}+\ldots \beta_{J} X_{i k}+\varepsilon_{i}$ Equation 5

Where: $\mathrm{Y}_{\mathrm{ij}}$ is the observed adoption level $j$ by individual $i ; \beta$ is a vector of coefficients associated with adoption factors and Xs are the adoption factors.
Conservation effort was evaluated basing on total value (in US\$) of investment made on conservation structures. The amount invested was regressed on the variables hypothesized to influence investment using a truncated regression model. Most independent variables were similar to those that influence adoption.

\section{RESULTS AND DISCUSSION}

Attributes of the resource users. Mean age for household heads in Kagarama was higher than those in Kacerere (Table 1). About 93\% of the households in Kacerere were maleheaded and $74 \%$ Kagarama. Household heads from both parishes had attained the same level of education (6 years in school). Area under crop production and number of plots that a household accesses for crop production were not sognificantly different across the two study parishes.

Ordered Logit Model results. The number of years of schooling by a household head, membership in a Farmer Field School (FFS)/ gravity flow scheme, number of extension visits, slope of the plot, total land acreage owned and perception of the NRM byelaws had positive and significant influence on adoption of conservation bye-laws; while sex of the household head, number of family labour days, decision making by a woman and primary economic activity of the household head had a negative and significant influence

TABLE 1. Selected socio-economic attributes of the respondents in Kacerere and Kagarama Parishes, Kabale District in Uganda

\begin{tabular}{lcc}
\hline Attribute & Kacerere parish (Bufundi) & Kagarama parish (Bubare) \\
\hline Age of household head (years) & 46.5 & 51.4 \\
Gender of household head (males) & $52(92.9 \%)$ & $45(73.7 \%)$ \\
Number of years of schooling & 5.69 & 5.57 \\
Household size & 5.61 & 5.03 \\
Crop plot size (ha) & 0.53 & 0.54 \\
Number of plots per household & 4.8 & 4.07 \\
\hline
\end{tabular}

Survey data, 2014 
on adoption of conservation bye-laws (Table 2).

The influence of education is consistent with a study by Ugwumba (2013), who found out that education level of farmers had a positive and significant influence in adoption of oil palm technologies in Nigeria. According to Patrick and Edna-Matthew (2002), good education in an area pre-disposes farmers to a balanced perception of new ideas and thus increases the chances of adoption.

Number of extension visits had the expected positive because access to extension increases farmers' confidence in adoption of conservation technologies (Habtemariam, 2004). On the other hand, the positive influence of membership to FFS or church-based gravity scheme was because such members had received sensitisation about soil degradation, and thus appreciated conservation intervention efforts. Such farmers perceive the conservation byelaws to be relevant, hence justifying their adoption.
The negative influence of family labour force was contrary to our expectation that households with larger family labour would easily adopt the bye-laws since they had the human power to establish conservation structures. Constistent with our findings, Chepng'etich et al. (2015) found that family labour was less efficient.

The negative influence of gender was partly due to the fact that most of the farming activities were done by women, who experienced the erosion effects. Most men were involved in non-farm activities and did not envision the need to adopt conservation measures. The same applies to trading, as an economic activity. Household heads that wereprimarily involved in trading, were less likely to adopt conservation technologies, and hence the negative and significant sign on primary economic activity (Trader) Table 2. Also, that if farming decisions are taken by women, households are likely not to adopt the conservation bye-laws. Adoption requires

TABLE 2. Determinants of adoption of NRM conservation byelaws in Bufundi and Bubare IPs, Kabale District in Uganda

\begin{tabular}{lcc}
\hline Explanatory variable & Coefficient & Standard error \\
\hline Age of household head (years) & 0.031 & 0.021 \\
Sex of household head (1=male; $0=$ female) & $-1.972^{* *}$ & 1.025 \\
Education of household head (years spent in school) & $0.344^{* * *}$ & 0.104 \\
Membership to FFS/Church & $1.885^{* *}$ & 0.941 \\
Primary economic activity (1=farming=1, 0=otherwise & -0.866 & 0.939 \\
Primary economic activity (1=trader, 0=otherwise) & $-2.936^{*}$ & 1.660 \\
Primary economic activity (1=civil service, $0=$ otherwise) & -1.638 & 1.360 \\
Number of extension visits received & $3.146^{* * *}$ & 0.855 \\
Family labour use (labour days) & $-0.332^{*}$ & 0.172 \\
Decision-making (1= woman, 0=otherwise) & $-1.957^{* *}$ & 0.917 \\
Decision-making (1=man and woman, $0=$ otherwise & 1.009 & 0.678 \\
Slope (1=steep, 0=otherwise) & $1.256^{* *}$ & 0.544 \\
Total land acreage (ha) & $0.368^{*}$ & 0.201 \\
Perception of byelaw (1=relevant, $0=$ otherwise) & $1.556^{*}$ & 0.892 \\
& & \\
Number of observations & 117 & \\
Log likelihood $\chi^{2}$ value & $89.8^{* * *}$ & \\
Loglikelihood & -49.578 & \\
Pseudo $\mathrm{R}^{2}$ & 0.475 & \\
\hline
\end{tabular}

Survey data, 2014 
TABLE 3. Determinants of conservation effort in Bufundi and Bubaare IPs in Southwestern Uganda

\begin{tabular}{llc}
\hline Explanatory variable & Coefficient & Standard error \\
\hline Age of household head (years) & -91499 & 77940.8 \\
Education of household head (years spent in school) & 18114.3 & 21721 \\
Dependence ratio & $-987474.9^{* *}$ & 472895 \\
Primary economic activity (1=civil service, $0=$ otherwise) & -565886 & 404466 \\
Secondary economic activity (1=trader, 0=otherwise) & -30973 & 272331 \\
Total land acreage (Ha) & -3365.7 & 9574.35 \\
Slope(1=steep,0=otherwise) & -164816 & 168625 \\
Number of extension visits & -24491 & 359586 \\
Value of livestock (US\$) & $0.1594158^{*}$ & 0.08786 \\
Plot distance (Km) & -49884 & 34304.3 \\
Obtained credit (1=yes; $0=$ otherwise) & $576977.7^{* *}$ & 254215 \\
Membership to FFS/Church & $600492.4^{*}$ & 357191 \\
Crop income (US\$) & 0.00161 & 0.2792 \\
Value of assets (US\$) & $-0.3664234^{*}$ & 0.19859 \\
Off-farm income (US\$) & $0.9071313^{* *}$ & 0.43521 \\
Constant & -120369 & 605846 \\
Number of observations & & \\
Log likelihood & 90 & \\
Wald $\chi^{2}$ & -1148.8 & \\
Sigma & 9.23 & \\
\hline
\end{tabular}

Survey data, 2014

more labour investment that a woman decision maker is not likely to commit herself to making this investment.

Truncated regression model results. Value of livestock, access to credit, membership to FFS/gravity scheme and off-farm income had positive and significant effects on conservation effort; while dependency ratio and household's total value of assets had a negative and significant influence (Table 3). The explanation for the positive effect of value of livestock was that livestock owners had wide income base that they used to invest in conservation activities. Households with more off-farm income were more likely to invest in conservation. It's likely, that conservation effort was highly linked to activities and enterprises that created income and wealth for the household.

The negative effect of household dependency ratio (estimated as the ratio of children under the age of 18 years to total household size) was due to higher expenditure (food, closing, school fees, medical) that households with higher dependency ratio have, which leaves them with no money that can be invested in conservation. The negative effect of value of assets owned by a household was that households with higher value of assets also have more income-generating activities, making farming less attractive to them, hence less investment.

\section{CONCLUSION}

Involvement in collective action influence both dependent variables, hence farmers should be mobilised and facilitated to work collectively. Extension visits should also be increased as they influence adoption positively. Male households are less likely to adopt yet they are the majority, hence deliberate efforts should be put in place to encourage them to participate in soil conservation. Access to credit increases investment in conservation. Establishing soil 
conservation requires a substantial investment hence need for access to credit opportunities. In line with financing, the existing collective action groups could introduce a savings and credit facility in their group as an alternative to external funding.

\section{REFERENCES}

Agrawal, A. and Ostrom, E. 2001. Collective action, property rights and decentralisation in resource use in India and Nepal. Politics and Society 29(4):485-514. Sage publications.

Chepng'etich, E., Nyamwaro, S., Bett, K.E, and Kizito, K. 2015. Factors that influence technical efficiency of sorghum production: A case of small holder sorghum producers in Lower Eastern Kenya. Advances in Agriculture. Article ID 861919 pp. 1-11.

Feleke, S. and Zegeye, T. 2006. Adoption of improved maize varieties in Southern Ethiopia: Factors and strategy options. Food Policy 31(5): 442-457.

Fritz-Vietta, N. Rottger,V. and Stoll-Kleemann, S. 2009. Community based management in 2 biosphere reserves in MadagascarDistinction and similarities: What can be learnt from different approaches? Madagascar Conservation and Development 4 (2):86-97.

Greene, W.H. 1997. Econometric analysis. Third Edition. Prentice Hall.

Greene, W.H. 2002. Econometric analysis. Fifth Edition. Prentice Hall.

Habtemariam, A. 2004. The comparative influence of intervening variables in the adoption behavior of maize and dairy farmers in Shashemene and Debre Zeit,
Ethiopia. Thesis for Award of PhD Degree at, University of Pretoria, South Africa.

ICRA. 2012. ICRA learning resources-Key Concepts (www.icra-edu.org) Accessed $31^{\text {st }}$ October 2014.

Mazengia, W. and Mowo, J. 2012. Role of collective actions in integrated soil and water conservation: The case of Gununo watershed, Southern Ethiopia. Journal of Development and Agricultural Economics 4(1):23-36.

Ratner, B., Meinzen-Dick, R., May, C. and Haglund, E. 2013. Resource conflict, collective action, and resilience: An analytical framework. International Journal of the Commons 7(1):183-208. Igitur publishing.

Sanginga, P., Kamugisha, R. and Martins, A. 2007. The dynamics of social capital and conflict management in multiple resource regimes: A case of the southwestern highlands of Uganda, Ecology and Society, 12(1):6, available at http://www.ecologyand society.org/vol12/iss1/art6/ Accessed 31 ${ }^{\text {st }}$ October 2014.

Train, K. 2003. Discrete choice methods with simulation. Cambridge University Press.

Ugwumba, C.O.A. 2013. Adoption of oil palm production technologies in Aguata Local Government Area of Anambra State, Nigeria.

Wade, R. 1987. The management of common property resources: Collective action as an alternative to privatisation or state regulation, Cambridge Journal of Economics 11:95-106.

Wolfe, E.C. 2013. Productive agriculture and NRM: Finding the synergy. Paper, Murrumbidgee, Landcare Inc.(MLi), Australia. 